\title{
Pheromone Mediated Sexual Reproduction of Pennate Diatom Cylindrotheca closterium
}

\author{
Franziska Klapper ${ }^{1}$ (D) Sien Audoor ${ }^{2} \cdot$ Wim Vyverman $^{2} \cdot$ Georg Pohnert $^{1,3}$
}

Received: 26 January 2021 / Revised: 6 April 2021 / Accepted: 13 April 2021 / Published online: 29 April 2021

(c) The Author(s) 2021

\begin{abstract}
Benthic diatoms dominate primary production in marine subtidal and intertidal environments. Their extraordinary species diversity and ecological success is thought to be linked with their predominantly heterothallic sexual reproduction. Little is known about pheromone involvement during mating of pennate diatoms. Here we describe pheromone guided mating in the

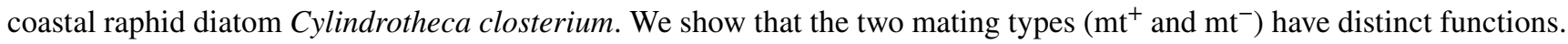
Similar to other benthic diatoms, $\mathrm{mt}^{+}$cells are searching for the $\mathrm{mt}^{-}$cells to pair. To enhance mating efficiency $\mathrm{mt}^{-}$exudes an attraction pheromone which we proved by establishing a novel capillary assay. Further, two more pheromones produced by $\mathrm{mt}^{-}$promote the sexual events. One arrests the cell cycle progression of $\mathrm{mt}^{+}$while the other induces gametogenesis of $\mathrm{mt}^{+}$. We suggest that $C$. closterium shares a functionally similar pheromone system with other pennate diatoms like Seminavis robusta and Pseudostaurosira trainorii which synchronize sexual events and mate attraction. Remarkably, we found no evidence of $\mathrm{mt}^{+}$producing pheromones, which differentiates $C$. closterium from other pennates and suggests a less complex pheromone system in C. closterium.
\end{abstract}

Keywords Mating Types · Cylindrotheca closterium $\cdot$ Pennate diatoms $\cdot$ Pheromones $\cdot$ Attraction assay $\cdot$ Cell cycle regulation

\section{Introduction}

Diatoms constitute a diverse group of photosynthetic unicellular microalgae and are key players in carbon cycling and nutrient exchange in marine and freshwater ecosystems (Armbrust 2009; Benoiston et al. 2017; Falkowski et al. 1998; Malviya et al. 2016; Smetacek 1998). Benthic raphid pennate diatoms are less studied than the predominantly planktonic group of centric diatoms. Yet, benthic diatoms contribute significantly to primary production in estuaries and coastal regions (Stal et al. 2019; Yallop et al. 1994)

Georg Pohnert

Georg.Pohnert@uni-jena.de

1 Bioorganic Analytics, Institute for Inorganic and Analytical Chemistry, Friedrich Schiller University Jena, Lessingstrasse 8, 07743 Jena, Germany

2 Laboratory of Protistology and Aquatic Ecology, Department of Biology, University Gent, Krijgslaan 281 S8, 9000 Gent, Belgium

3 Max Planck Institute for Chemical Ecology, Hans-Knöll-Straße 8, 07745 Jena, Germany where they frequently dominate biofilms and stabilize sediments. Recent genomic studies revealed their unique adaptations to this highly dynamic and heterogeneous environment (Osuna-Cruz et al. 2020). They show an extraordinarily high species diversity, thought to be driven by the evolution of motility and the transition to a heterothallism (Nakov et al. 2018).

Reproduction systems of raphid pennate diatoms have been intensively studied in the last decades (Amato 2010; Chepurnov et al. 2004; Poulíčková and Mann 2019). Asexual division prevails during the diplontic life cycle of diatoms and is accompanied by a gradual cell size reduction. Meiosis and subsequent sexual reproduction, however, are vital to restore original cell size. Typically, sexual reproduction is triggered when cells reach a species-specific sexual size threshold (SST, $\sim 50 \%$ of their original size) (Chepurnov et al. 2002; Davidovich 2001), following pair formation between sexually compatible mating types (hereafter referred to as $\mathrm{mt}$ if cells $<\mathrm{SST}$, and as MT if cells $>$ SST). Although mating types are morphologically indistinguishable, mating type determination has a genetic basis (Vanstechelman et al. 2013; Russo et al. 2018) and 
is reflected in behavioural and physiological differentiation. For example, in Seminavis robusta, $\mathrm{mt}^{-}$cells produce the attraction pheromone cycLo(L-Pro-L-Pro) (L-diproline), guiding the more motile $\mathrm{mt}^{+}$cells towards them (Chepurnov et al. 2005, 2002).

Mate finding and sexual reproduction are energetically costly (Lewis 1987) and pheromones of different chemial and structural classes can increase mating probability and efficiency (Basu et al. 2017; Frenkel et al. 2014). In the planktonic diatom $P$. multistriata a pheromone is suggested to synchronize the sexual events (Scalco et al. 2014) whereas three different consecutively induced pheromones are thought to be involved in the reproduction of the freshwater diatom Pseudostaurosira trainorii to control sexualization of cells and orientate gametes (Sato et al. 2011). Mating of S. robusta was studied intensively and is also promoted by three distinct pheromones (Bilcke et al. 2020; Bondoc et al. 2019, 2016; Chepurnov et al. 2002). Two sex inducing pheromones $\mathrm{SIP}^{+}$ and $\mathrm{SIP}^{-}$are produced by $\mathrm{mt}^{+}$and $\mathrm{mt}^{-}$, respectively, and synchronize the cell cycle (Moeys et al. 2016). Pheromone structures are poorly studied (Bonneure et al. 2021) but the chemoattractant of $S$. robusta was identified as 1-diproline, the first elucidated attraction pheromone of a diatom (Gillard et al. 2013). The $\mathrm{mt}^{-}$cells that are exposed to $\mathrm{SIP}^{+}$release $\mathrm{L}$-diproline to attract $\mathrm{mt}^{+}$cells.

The pennate diatom Cylindrotheca closterium (Ehrenberg) Reimann \& J.C.Lewin is a meroplanktonic species, exploiting both planktonic and benthic habitats and can be abundant in water columns as well as biofilms. As it is found in marine, brackish, freshwater regions and even inside seaice (von Quillfeldt et al. 2003), C. closterium has been used as model in several eco-physiological studies showing its ability to adapt to varying temperatures (Stock et al. 2019) and salinities (Najdek et al. 2005). The unique movement modalities of $C$. closterium also change in response to hypoor hyper-saline conditions (Apoya-Horton et al. 2006). In recent years even a transformation protocol has been established for $C$. closterium and a gene editing protocol through CRISPR/Cas9 is currently developed, thus providing a toolbox for many molecular studies as well (unpublished data).

The life cycle of $C$. closterium has also been studied in detail (Vanormelingen et al. 2013). When cells reach the SST ( $70 \%$ of their original size) and partners of the two distinct mating types, Cyc1 and Cyc2 meet, sexual reproduction takes place resulting in two cells with the initial cell size. The purpose of this study was to specify the mating behaviour of each mating type and investigate whether there is an attracted $\left(\mathrm{mt}^{+}\right)$and an attracting $\left(\mathrm{mt}^{-}\right)$partner. Further, we aimed to determine if a directed attraction during mate finding occurs. The possibility of pheromone involvement during mating in C. closterium was also investigated and similarities and disparities in the mating systems of pennate benthic diatoms are discussed.

\section{Methods and Material}

\section{Strains, Culture Conditions and Microscopy}

C2 (DCG 0977, Cyc1, identified as $\mathrm{mt}^{+}$(see below)) and CA1.15 (DCG 0923, Cyc2, identified as $\mathrm{mt}^{-}$(see below)) strains of Cylindrotheca closterium, both sexually mature (cell size: Cyc1 $<50 \mu \mathrm{m}, \mathrm{Cyc} 2<30 \mu \mathrm{m}$ ) and $\mathrm{CZ1}\left(\mathrm{MT}^{-}>60 \mu \mathrm{m}\right.$; $\left.>\mathrm{SST}\right)$ were provided by the BCCM/ DCG diatom culture collection at Ghent University (http:// bccm.belspo.be/about-us/bccm-dcg). Cultures were grown in $\mathrm{f} / 2+$ Si medium (Guillard 1975) in a 12:12 h light:dark regime at $18{ }^{\circ} \mathrm{C}$ with fluorescent lamps at $\sim 30 \mu \mathrm{mol}$ photons $\mathrm{m}^{-2} \mathrm{~s}^{-1}$. Stocks were kept in T-25 tissue culture flasks (10 mL, Sarstedt, Nümbrecht, Germany) and reinoculated every week to keep them in exponential growth.

To estimate cell density by microscopically counting and surveying experimental results, photographs of each culture $(n=3)$ were taken with a Nikon DS-Fi2 CCD camera (Tokyo, Japan) attached to an inverted Leica DM IL LED light microscope (Heerbrugg, Switzerland) (100 $\mathrm{x}$ magnification). The open-source software ImageJ (Rasband WS, ImageJ, U. S. National Institutes of Health, Bethesda, Maryland, USA. http://imagej.nih.gov/ij/1997) and the cell counter plug-in was used for counting cells as well as pairs and clusters of cells in mating experiments.

For experiments, cultures were first grown in 6-well plates ( $5 \mathrm{~mL}$ well ${ }^{-1}$, Sarstedt, Nümbrecht, Germany) for 4 days to reach early exponential phase. Thereafter cultures were dark-synchronized for $36 \mathrm{hrs}$ (Vanormelingen et al. 2013).

\section{Clustering Experiment}

For mating type designation, dark arrested cultures of compatible strains were crossed in triplicates in 5 different density ratios, 1:9, 3:7, 5:5, 7:3 and 9:1 in 24 well plates, having monoclonal cultures as control. Each well contained $500 \mu \mathrm{L}$ of spent medium of each strain and $200 \mu \mathrm{L}$ of cell suspension $\left(30 \cdot 10^{3}\right.$ cells $\left.\mathrm{cm}^{-2}\right)$ composed of the above mentioned mating type proportions. Five hours after re-illumination the mating response was evaluated by manually analysing microscopic photographs. Cells of the two mating types were distinguished by the differing apical cell length. The following classes of interacting cells were discriminated: mating-pairs (two cells of different mating type laying against each other with their long axes parallel), multiple pairing cluster (accumulation of cells in which the mating type of the majority is three times more present than the other), as well as the total number of interactions (pairs, clusters and triplets). 


\section{Capillary Assay}

For the investigation of cell attraction, dark-synchronized cultures of $\mathrm{mt}^{+}$were split into 12 -well plates in new $\mathrm{f} / 2$ medium and kept at light for six hours. For the investigation of cell attraction, dark-synchronized cultures of $\mathrm{mt}^{+}$were split into 12-well plates in new $\mathrm{f} / 2$ medium and kept at light for six hours.

Two hundred millilitres of cell free medium of exponentially growing cultures of C2, CA1.15 and CZ1 $\left(\mathrm{mt}^{+}\right.$, $\mathrm{mt}^{-}$and $\mathrm{MT}^{-}$(>SST) respectively) alike were extracted using HLB cartridges (hydrophilic-lipophilic balanced solid phase extraction, Oasis®, Waters, Eschborn, Germany) following the instructor's manual. $\mathrm{MeOH}$ extracts were dried under nitrogen flow and dissolved in $200 \mu \mathrm{L}$ pure water (LC/ MS grade).

Capillaries ( $1=30 \mathrm{~mm}, \mathrm{~V}=5 \mu \mathrm{L}$, minicaps, Hirschmann, Germany) were prepared directly before use $(n=4)$. Therefore, $25 \mu \mathrm{L}$ of medium extract were added $(1: 1 \mathrm{v} / \mathrm{v})$ to hot agar (2\% Agar-Agar, Kobe 1, Roth, Germany), mixed quickly and immediately absorbed into the capillaries by capillary forces. The outside of the capillaries was cleaned carefully and the capillaries were air-dried for five minutes. Capillaries were then carefully placed vertically in the wells which were covered by a plastic foil holding the capillaries in place.

Pictures of the capillary openings were taken at $\mathrm{t}=0 \mathrm{~min}$ (directly after inserting the capillary), $\mathrm{t}=30 \mathrm{~min}$, and $\mathrm{t}=$ $60 \mathrm{~min}$ and cells were counted within a defined area of $\mathrm{d}=$ $580 \mu \mathrm{m}$ around the capillary (ImageJ).

\section{Motility Assay}

In 24-well-plates, dark arrested cultures of $\mathrm{C} 2\left(\mathrm{mt}^{+}\right)$and CA1.15 $\left(\mathrm{mt}^{-}\right)$were treated with $1.5 \mu \mathrm{L}$ of medium extract of the opposite mating type $(n=4)$ (see Capillary Assay for extract preparation) four hours after re-illumination. Control cultures stayed untreated. In C2 experiments three individual videos $(30 \mathrm{~s})$ were recorded (1fps) for each well one hour after the treatment to verify the robustness of the assay. In experiments with CA1.15 one video was recorded for each replicate. Cell tracking was done for $>300$ cell per replicate using the plug-in TrackMate (http://fiji.sc/TrackMate) for ImageJ.

\section{G1 Cell Cycle Arrest Assay}

Five millilitres of medium of exponentially growing cultures of $\mathrm{C} 2$ and CA1.15 (mt ${ }^{+}$and $\left.\mathrm{mt}^{-}\right)$were sterile filtered (Filtropur S $0.2 \mu \mathrm{m}$, Sarstedt, Germany) immediately before the experiment. Dark-arrested cultures were split for different treatments two hours before re-illumination. In the dark, culture medium of treatments was fully exchanged by filtered medium of the opposite mating type while control cultures stayed untreated.

At $\mathrm{t}=0 \mathrm{hrs}$ (in the dark) and $\mathrm{t}=6 \mathrm{hrs}$ (after re-illumination), $2 \mathrm{~mL}$ samples were taken and directly centrifuged (5 min, 3000 $\mathrm{rpm})$. The supernatants were discarded and directly replaced by ice-cold $70 \%$ ethanol. These fixed samples were stored at $4{ }^{\circ} \mathrm{C}$ in the dark for at least $24 \mathrm{hrs}$. The supernatant was discarded and cell pellets were resuspended in $200 \mu \mathrm{L} 70 \%$ ethanol and washed twice with phosphate-buffered saline (PBS, $137 \mathrm{~mm}$ $\mathrm{NaCl}, 2.7 \mathrm{~mm} \mathrm{KCl}, 10 \mathrm{~mm}$ phosphate, $\mathrm{pH}$ 7.4). Samples were treated with $1 \mu \mathrm{g} \mathrm{mL}-1$ RNAse A for $40 \mathrm{~min}$ at $37^{\circ} \mathrm{C}$ and afterwards stained with SybrGold (10,000 fold diluted from stock solution, SYBR Gold Nucleic Acid Gel Stain, Thermo Fisher Scientific, USA) for $10 \mathrm{~min}$ in the dark. Cells were transferred to PBS again and filtered over Celltric filters (Sarstedt, USA) to exclude cell clusters. DNA content was measured on a BC Accuri C6 flow cytometer. For each sample, 5000 events were collected and gated in the FL1 and FSC channel. G1 and G2+M peaks were visually selected and statistically analysed.

\section{Gametogenesis}

Gametogenesis was induced by crossing dark arrested cultures of $\mathrm{mt}^{+}$and $\mathrm{mt}^{-}(\mathrm{n}=3)$ in 24 well plates in either 1:9 or $9: 1$ ratio. Each well contained $500 \mu \mathrm{L}$ of spent medium of each strain and $100 \mu \mathrm{L}$ of cell suspension $(30 \cdot 103$ cells $\mathrm{cm}-2)$ adjusted to the given proportions and cell densities of the pre-cultures. Over a period of five days, gamete formation and initial cell formation was evaluated.

\section{Statistical Evaluation}

All data are depicted as mean \pm standard error of the mean. The statistical analysis was done with square root transformed data in the open-source statistical program $\mathrm{R}$ v.4.0.3. (Team 2016). After testing for normal distribution and equal variances, effects were evaluated by applying One-Way ANOVA $(\alpha=0.05)$ and a subsequent Tukey's multiple comparison post-hoc test. In case of the clustering experiment multivariate analysis was applied to consider two dependent outcome variables (pairs and clusters) using the package MANOVA.rm (Friedrich et al. 2018). A Mann-Whitney rank sum test was applied to compare two groups. 


\section{Results}

\section{Designation of Mating Types in Cylindrotheca closterium}

To detect characteristics of mate finding and searching behaviour in Cylindrotheca closterium compatible strains of mating type (mt) Cyc1 and Cyc2 (Vanormelingen et al. 2013) were crossed in different ratios (Fig. 1). The strong accumulation of Cyc1 cells around Cyc2 cells revealed the attracting nature of $\mathrm{Cyc} 2$ cells and leads to the assignment of Cyc2 to mating type $\left(\mathrm{mt}^{-}\right)$. Cells of Cyc1, on the other hand, seemed to be more motile searching for the opposite partner and thus representing mating type $e^{+}\left(\mathrm{mt}^{+}\right)$. Pair formation as well as cell cluster formation of distinct mating types were recognized by the differing cell lengths of both mating types. Cell clusters consist of at least three times more cells of the dominant mt (Fig. 1a). $\mathrm{Mt}^{+}$cells that were either smaller or bigger than $\mathrm{mt}^{-}$both showed clustering around $\mathrm{mt}^{-}$(Fig. S1) which confirms that searching behaviour is independent of cell size concerning $\mathrm{mt}^{+}$. Crosses with an equal number of both mating types (5:5) resulted in most successful mating (11.7.10 total interactions $\mathrm{cm}^{-2}$ out of $15 \cdot 10^{3}$ possible pairs) comprising formation of pairs, clusters and triplets (Fig. 1b). As the proportion changed towards one mating type total interactions were limited by the partner present in the lower density and thus less interactions $\mathrm{cm}^{-2}$ were monitored. In crosses with a low $\mathrm{mt}^{+}: \mathrm{mt}^{-}$ratio cells mostly formed pairs (40-60\% of total interaction, Fig. 1c). Pair formation also dominated the crosses of equal mating type ratio, comprising almost two thirds of all interactions. With a descending proportion of $\mathrm{mt}^{-}$cells accumulations of $\mathrm{mt}^{+}$cells around $\mathrm{mt}^{-}$cells occurred. Clusters were even most prevalent in crosses with a majority of $\mathrm{mt}^{+}$cells. In the $9: 1$ cross, clusters dominated the culture comprising more than $85 \%$ of all total interactions $\left(4.2 \cdot 10^{3}\right.$ clusters $\left.\mathrm{cm}^{-2}\right)$. Clusters were still detected in crosses with a low $\mathrm{mt}^{+}: \mathrm{mt}^{-}$ratio but in a comparably low amount (10-30\% of total interactions). Taken

a

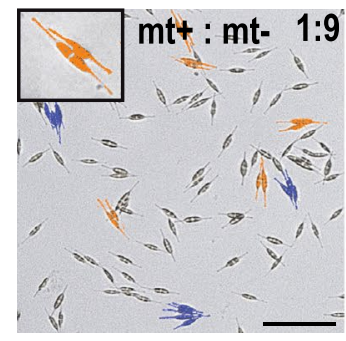

b

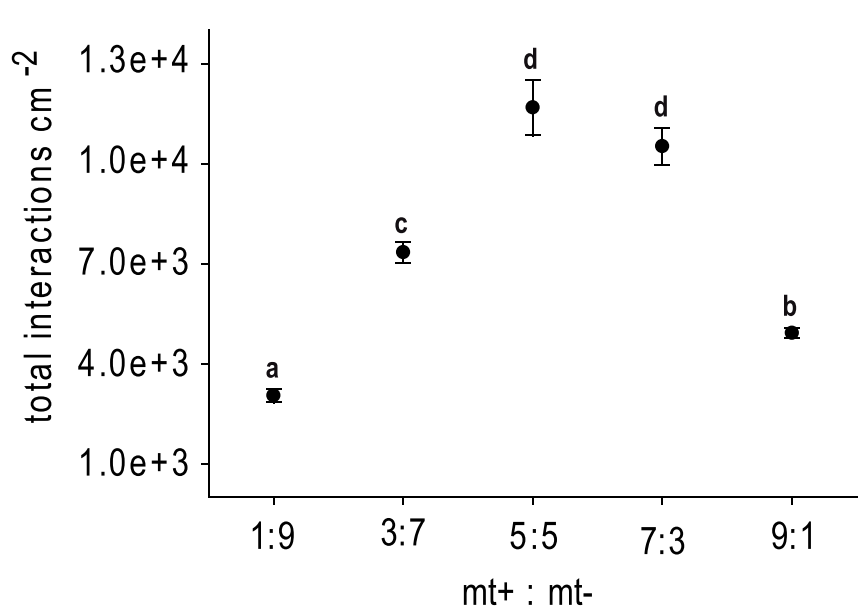

Fig. 1 Mating type determination in Cylindrotheca closterium. Crosses of Cyc1 $\left(\mathrm{mt}^{+}\right)$and $\mathrm{Cyc} 2\left(\mathrm{mt}^{-}\right)$in different ratios $5 \mathrm{hrs}$ after mating, leading to the identification of the respective mating type. a Inverted microscope images of the crosses showing an increase of clusters (blue, at least 3:1 cells of the prevailing strain) when Cyc1 cells become prevalent. Most paired cells (orange) can be seen when $\mathrm{Cyc} 1$ and $\mathrm{Cyc} 2$ are present in similar numbers. Scale $=100 \mu \mathrm{m} \mathbf{b}$
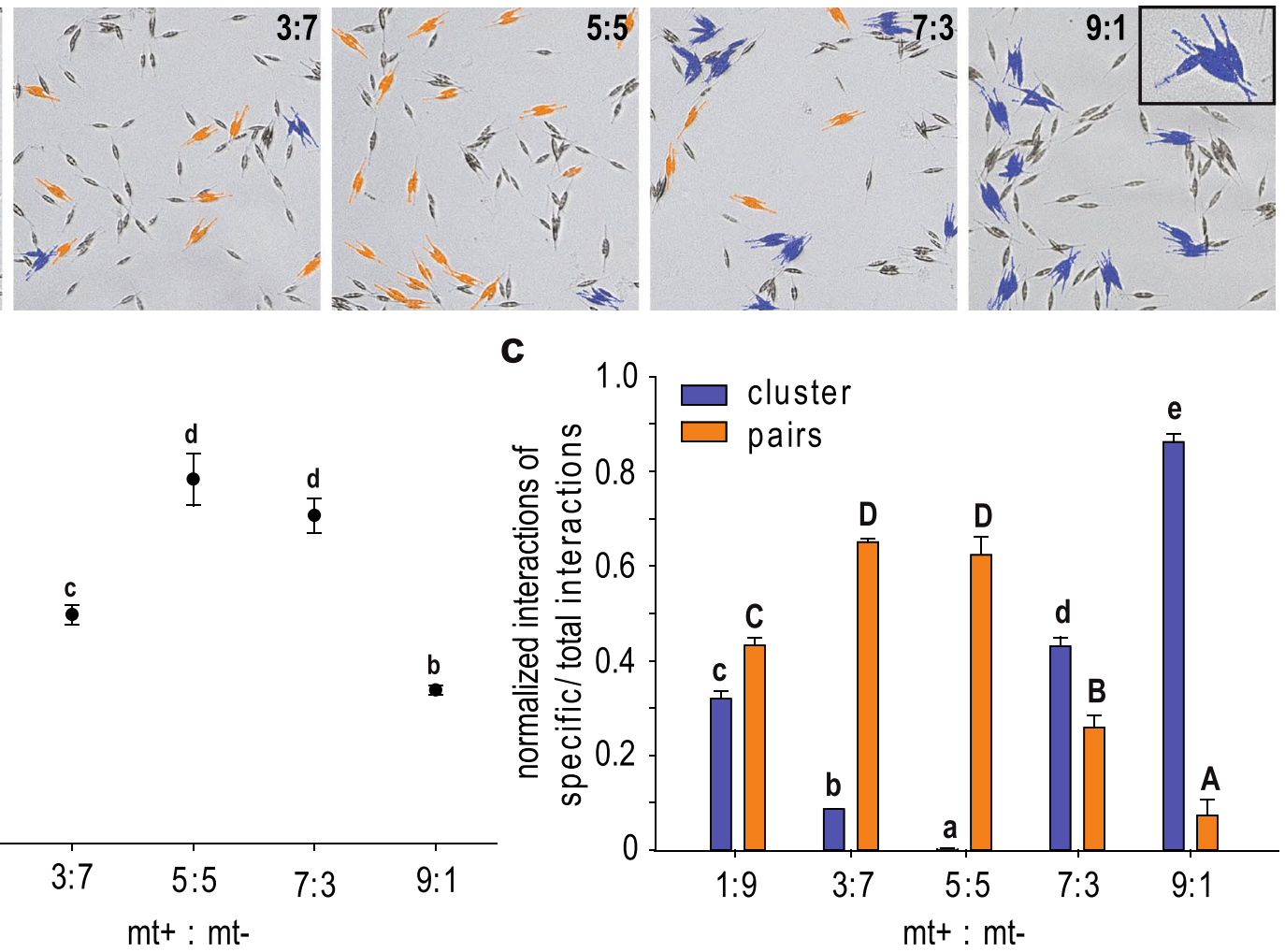

Means \pm s.e. $(n=3)$ of total sexual events, c clusters (blue bars), and pairs (orange bars) depending on different mating type ratios. Significance was calculated with a one-way ANOVA (b) or a multivariate ANOVA (c) ( $\alpha=0.05$, Tukey's multiple comparison post-hoc test). Letters $\mathbf{a}, \mathbf{b}, \mathbf{c}, \mathbf{d}$ and $\mathbf{e}$ and letters $\mathbf{A}, \mathbf{B}, \mathbf{C}$, and $\mathbf{D}$ represent statistically significantly different groups $(\mathrm{p}<0.001)$ 
together, these data show that each mating type has a specific behaviour and a defined functional purpose that shapes and structures the mate finding process.

\section{Bioassay Reveals Chemical Mediated Attraction of $\mathbf{m t}^{+}$}

We hypothesized that chemical signalling is involved in the mate finding process of $C$. closterium. To verify this hypothesis, $\mathrm{mt}^{+}$cell attraction towards $\mathrm{mt}^{-}$exudates was assessed. Exudates could be extracted via solid phase extraction using methanol as an eluant. A chemotaxis assay comprised of capillaries filled with medium extracts embedded in agar was optimized to meet the requirements of using benthic algae instead of bacteria (Abe et al. 2017). Extracts diffuse from small capillaries that are placed on the bottom of a well (Fig. 2a). Careful optimization included the use of smaller capillaries ( $5 \mu \mathrm{L}$ instead of $20 \mu \mathrm{L}$ ) that were placed vertically in the well. A foil, holding the capillaries ensured a stable set-up and was required to counteract the extreme variability in initial experiments (Fig. S2) and increased robustness of this delicate procedure dramatically.

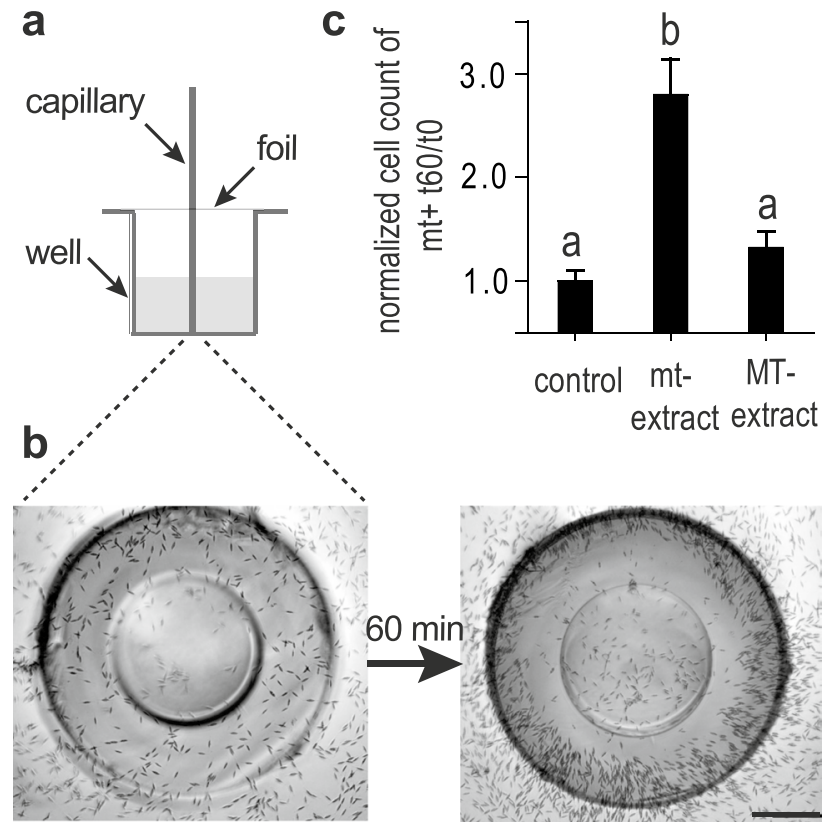

Fig. 2 Chemical attractionof $\mathrm{mt}^{+}$cells towards $\mathrm{mt}^{-}$cells in C. closterium. In achemoattraction assay glass capillaries were filled with different mediumextracts embedded in agar tomonitor $\mathrm{mt}^{+}$cell accumulation around it. a Scheme ofcapillary assay. b Capillary filled with $\mathrm{mt}^{-}$medium extract in agar is depicted(picture is taken from below the set-up) at the start of the experiment (left). $\mathrm{mt}^{+}$cells accumulated around the capillary after $60 \mathrm{~min}$ (right).Pictures were grey scale adjusted. Scale $=200 \mu \mathrm{m}$ c Comparisonof $\mathrm{mt}^{+}$cell accumulation $\left(\mathrm{t}_{60 \mathrm{~min}} / \mathrm{t}_{0 \mathrm{~min}}\right)$ aroundcapillaries filled with medium extract of $\mathrm{mt}^{+}$(control) and of $\mathrm{mt}^{-}<\mathrm{SST}\left(\mathrm{mt}^{-}\right)$and $>\mathrm{SST}\left(\mathrm{MT}^{-}\right),(\mathrm{n}=4)$. Significance was calculated with one-way ANOVA ( $\alpha=0.05$, Tukey test). Letters $\mathbf{a}$ and $\mathbf{b}$ represent significantly different groups $(\mathrm{p}<0.001)$
Capillaries filled with $\mathrm{mt}^{-}$medium extracts led to an accumulation of $\mathrm{mt}^{+}$cells around the capillary opening 60 min after inserting the capillary (Fig. 2b). Cell counting revealed almost three times more $\mathrm{mt}^{+}$cells around target capillaries than around control capillaries. Controls contained extract of the same mating type and showed no activity since cell numbers around the capillaries did not increase over time (Fig. 2c). We therefore suggest that $\mathrm{mt}^{+}$cells must have received a signal from the $\mathrm{mt}^{-}$medium extract within the capillary and accumulated at its highest concentration. As expected, extracts of $\mathrm{MT}^{-}$cultures (sexually immature; $>$ SST) did not trigger a response of $\mathrm{mt}^{+}$cells.

Further, $\mathrm{mt}^{+}$cells also responded to $\mathrm{mt}^{-}$medium extract by changing their motility behaviour. One hour after exposure to $\mathrm{mt}^{-}$medium extract, $\mathrm{mt}^{+}$cells employed chemokinesis resulting in an increase of the overall mean speed (Fig. 3a). $\mathrm{Mt}^{+}$cells were 2.7 times faster compared to control cultures. Likewise, the travelled net distance of treated $\mathrm{mt}^{+}$cells also increased (Fig. 3b) which enhances mate finding. As expected, $\mathrm{mt}^{-}$cell motility was not affected by medium extract of $\mathrm{mt}^{+}$(Fig. 3c, d).

This leads to the assumption that a chemical cue is exuded by $\mathrm{mt}^{-}$cells as soon as they fall below the sexual size threshold (SST). The sexually mature cells start to constitutively

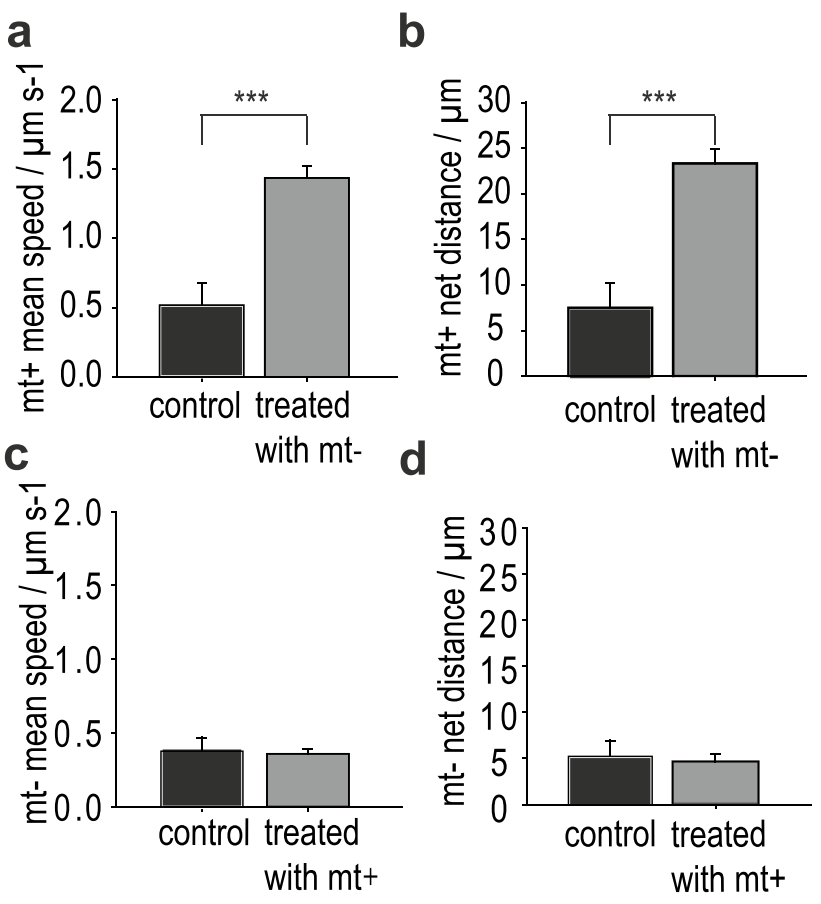

Fig. 3 Chemokinesis in C. closterium. In a motility assay, cells were exposed to medium extract of the opposite mating type $(n=4)$. a The overall mean speed of $\mathrm{mt}^{+}$cells in the treatment is almost three times higher than in the control. b Displacement analysis of treated $\mathrm{mt}^{+}$ cells showed a significantly higher travelled net distance in $30 \mathrm{~s}$. c, d Treated $\mathrm{mt}^{-}$cells did not change regarding their mean speed or the distance they travelled compared to the control. Significance was calculated with a Mann-Whitney rank sum test $(p<0.001)$ 
produce this attraction pheromone without further induction. This pheromone plays an essential role in guiding $\mathrm{mt}^{+}$cells and proves chemical involvement in the mate finding process of $C$. closterium to increase mating efficiency.

\section{Cell Cycle Regulation of $\mathbf{m t}^{+}$During Mating}

Besides cell attraction, we investigated cell cycle regulations of $C$. closterium during mate finding. DNA content was measured with flow cytometry and reflected the cell cycle phases (G1, S+G2) of the cells. Initially, cultures of both mating types were successfully synchronized in their cell cycle by dark treatment as described by Vanormelingen et al. (2013). Cells were kept almost solely in G1 phase (>95\%) of the cell cycle (Fig. 4a, top) and less than $5 \%$ of the cells entered the $\mathrm{S}+\mathrm{G} 2$ phases of the cell cycle (Fig. 4b, black). As expected, at least $20 \%$ of the cells proceeded into the $\mathrm{S}+\mathrm{G} 2$ phases of the cell cycle 6 hrs after illumination (Fig. 4a, middle, Fig. 4b grey). A comparison of both mating types revealed that $\mathrm{mt}^{-}$spent medium caused an arrest of $\mathrm{mt}^{+}$cells in $\mathrm{G} 1$ phase that lasted for at least $6 \mathrm{hrs}$ (Fig. 4a, bottom). Surprisingly, $\mathrm{mt}^{-}$cells treated with $\mathrm{mt}^{+}$spent medium were not arrested but proceeded in the cell cycle. That contrasts the $\mathrm{mt}^{+}$cultures that were arrested in G1 phase in the presence of $\mathrm{mt}^{-}$spent medium.
Overall, it confirms that a chemical cue is exuded by $\mathrm{mt}^{-}$ cells and functions as a cell cycle regulation pheromone in C. closterium. The chemical signal is important upon the mating process only since medium of $\mathrm{MT}^{-}$cells ( $>\mathrm{SST}$, Fig. 4c) did not lead to an arrest of $\mathrm{mt}^{+}$cells in the cell cycle. Thus, the signal responsible for the cell cycle arrest in $\mathrm{mt}^{+}$ is only produced by sexually mature $\mathrm{mt}^{-}$cells and is crucial for the sexual reproduction of $C$. closterium.

\section{Gametogenesis of $\mathrm{mt}^{+}$is Triggered by Pheromone of $\mathbf{m t}^{-}$}

Lastly, we studied the mating process regarding gamete formation and subsequent initial cell formation over a period of 5 days (Fig. 5). Crossing cultures with a $\mathrm{mt}^{+}: \mathrm{mt}^{-}$ratio of either 1:9 or 9:1 resulted in equivalent numbers of initial cells. Compared to crosses with a more balanced mt ratio, these crosses were still efficient with respect to the numbers of compatible partners (Fig. S3). When mt cells were dominant, gametes of each mating type developed equally on the first day. Their numbers decreased over time while compatible gametes paired effectively and completely evolved into initial cells. Almost no gametes of either mating type were found after 5 days (Fig. 5a). In crosses with a high $\mathrm{mt}^{+}: \mathrm{mt}^{-}$cell ratio not only $\mathrm{mt}^{-}$cells but the majority of $\mathrm{mt}^{+}$cells developed into gametes. This led to an increase
Fig. 4 Cell cycle arrest of $\mathrm{mt}^{+}$ cells of $C$. closterium in $\mathrm{G} 1$ phase measured by flow cytometry. Cells were dark-synchronized in $\mathrm{G} 1$ phase $(\mathrm{G} 2<5 \%)$ and treated with spent medium of the opposite mating type. a DNA histograms of $\mathrm{mt}^{+}$cells showing a synchronized culture (top), a control culture (middle) and conditioned culture (bottom) $6 \mathrm{hrs}$ after illumination. b Comparison of $\mathrm{mt}^{+}$treated with $\mathrm{mt}^{-}$spent medium and vice versa. Treated $\mathrm{mt}^{+}$cells are arrested in G1 phase for at least $6 \mathrm{hrs}$. $\mathbf{c ~} \mathrm{Mt}^{+}$cells are only arrested by spent medium from $\mathrm{mt}^{-}(<\mathrm{SST})$ not by spent medium of larger $\mathrm{MT}^{-}$cells. Means $(n=3,4)$ of proportion of cells in $\mathrm{G} 2$ phase at $\mathrm{t}=0$ hrs (black) and $\mathrm{t}=6 \mathrm{hrs}$ after illumination (grey) are depicted. Significance was calculated with a one-way ANOVA ( $\alpha=0.05$, Tukey test). Letters a and $\mathbf{b}$ represent groups of nonsignificantly different distribution $(\mathrm{p}<0.0001)$ a
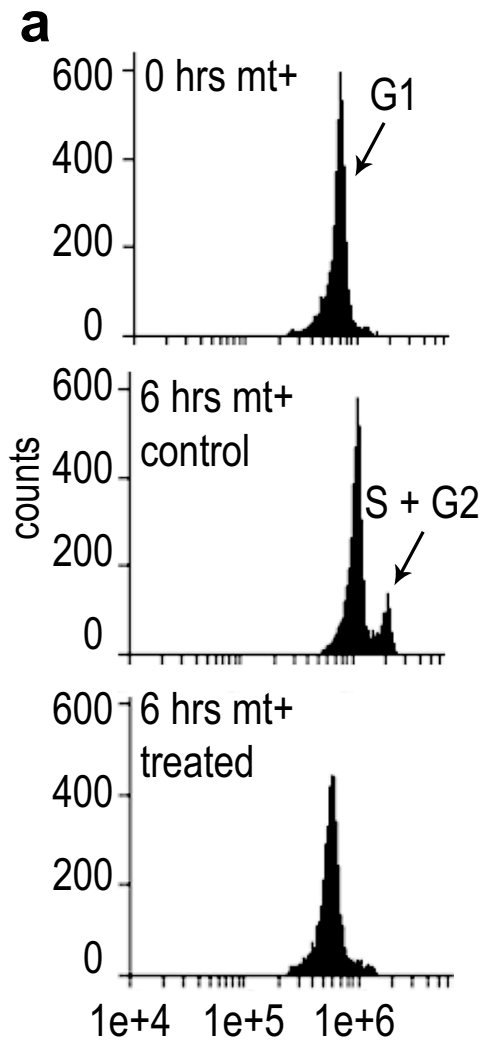

b
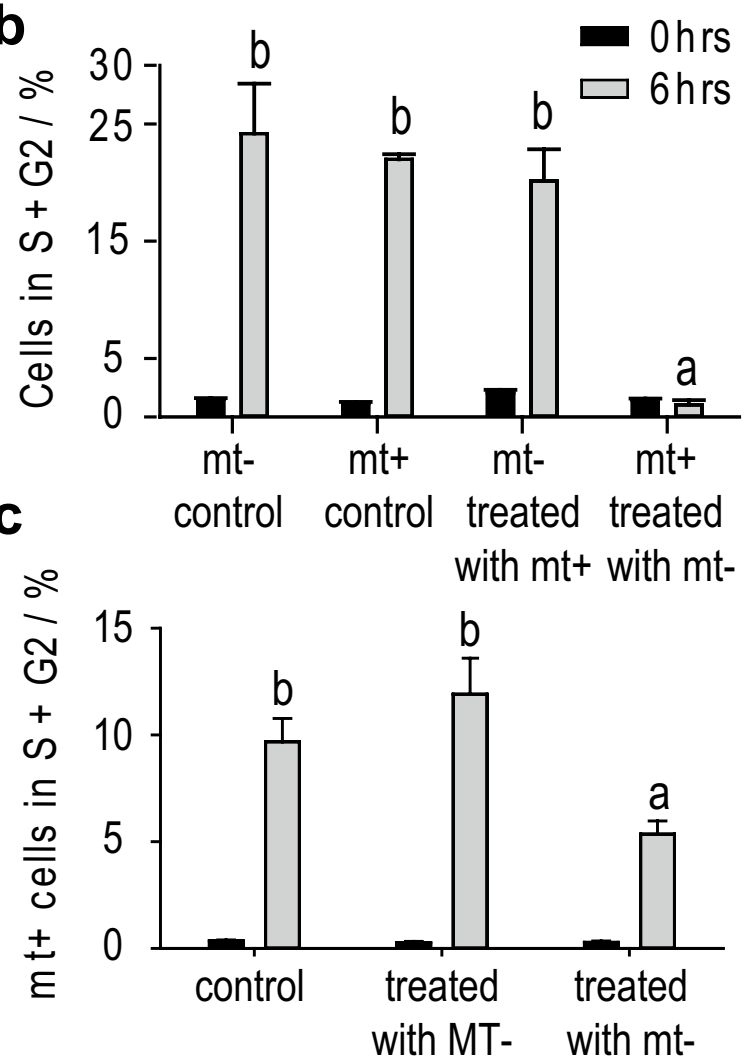
Fig. 5 Gametogenesis of $\mathrm{mt}^{+}$ and $\mathrm{mt}^{-}$cells. Crossing $\mathrm{mt}^{+}$ and $\mathrm{mt}^{-}$of $C$. closterium $(\mathrm{n}=3)$ resulted in gamete (bars) and initial cell (dots) formation, which were monitored for 5 days. a A mt ${ }^{+}$: $\mathrm{mt}^{-}$ratio of $1: 9$ showed a decrease of gametes among the increase of initial cells, whereas $\mathbf{b}$ a mating type ratio of 9:1 showed increasing numbers of gametes

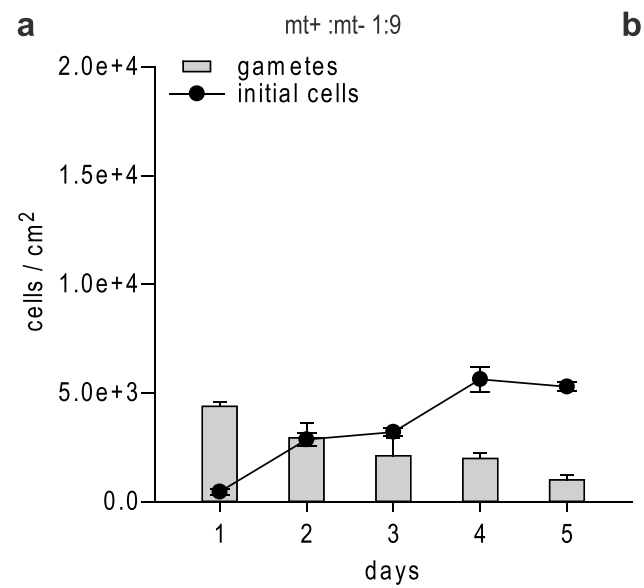

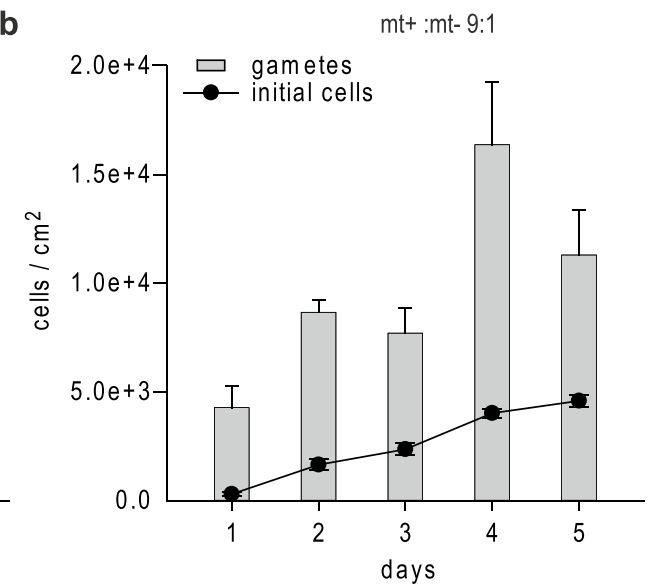

of $\mathrm{mt}^{+}$gametes over time. Facing an insufficient number of compatible partners only few gametes developed into initial cells (Fig. 5b). Again, we observed $\mathrm{mt}^{+}$cell clusters around $\mathrm{mt}^{-}$cells that resulted in an enhanced number of gametes. Gametes were only formed within those clusters (Vanormelingen et al. 2013). However, $\mathrm{mt}^{+}$cells within the cluster, but with no direct contact to $\mathrm{mt}^{-}$cells also evolved into gametes. Non-pairing $\mathrm{mt}^{+}$cells were unaffected. This suggests that $\mathrm{mt}^{-}$cells exude another short living instable signal that induces gametogenesis in $\mathrm{mt}^{+}$cells. Based on this experiment we suggest a third pheromone to be involved in the sexual reproduction of $C$. closterium and proved that not only mate finding but sexual reproduction itself is chemically mediated.

\section{Discussion}

We investigated the heterothallic mating system of the benthic pennate diatom Cylindrotheca closterium with respect to its distinct mating types (mt) and the pheromones that are involved in the process of mate finding. $C$. closterium has mating types of opposite sexes Cyc1 and Cyc2 (Vanormelingen et al. 2013) that are morphologically indistinguishable. We showed that each $\mathrm{mt}$, when it falls below the sexual size threshold (SST) fulfils a specific role, either to attract the partner $\left(\mathrm{mt}^{-}\right)$or to purposely search for it $\left(\mathrm{mt}^{+}\right)$. This suggests that mating behaviour in C. closterium is genetically predetermined. It resembles the mating system of Seminavis robusta (Vanstechelman et al. 2013), which also constitutes of an attracting partner and a more motile searching one as soon as the SST is reached (Gillard et al. 2013). In contrast, in Pseudo-nitzschia multistriata the behaviour of mating types was interpreted as being under the control of cell size (Scalco et al. 2016) since the larger strain, independently of the mating type, actively searches for the smaller, less motile strain. For most heterothallic diatom species mating types of parental cells are not categorized in '+' and '-', e.g. Haslea ostrearia, or Pseudo-nitzschia multistriata.
(D'Alelio et al. 2009; Davidovich et al. 2009) and their gametes are morphologically indistinguishable. However, assignment of male and female gametes is described frequently in araphid pennate diatoms, e.g. Tabularia fasciculate and Pseudostaurosira trainorii. Female gametes stay attached to the parental valves whereas the more motile male gametes facilitate contact with the females (Davidovich et al. 2010; Sato et al. 2011).

Notably, behaviour of $\mathrm{mt}^{+}$cells in $C$. closterium is pheromone guided. A signal released by $\mathrm{mt}^{-}$cells enables mate finding like in S. robusta (Gillard et al. 2013). The attraction bead assay used for $S$. robusta could not be employed since cells attached to the unloaded beads as well (Gillard et al. 2013). We therefore established a novel capillary assay in which $\mathrm{mt}^{+}$cells were attracted to medium extracts of $\mathrm{mt}^{-}$embedded in agar. A long response time of $\mathrm{mt}^{+}$cells resulted, most likely, from an incomplete diffusion of chemical signals from the capillary. We excluded a random encountering like it was shown in $P$. trainorii. Male gametes of $P$. trainorii only head directly towards female gametes after an initial "random walk" to come within a close range of opposite sex (Sato et al. 2011). In C. closterium, $\mathrm{mt}^{+}$cells response chemokinetically towards $\mathrm{mt}^{-}$exudates with respect to their pace. When $\mathrm{mt}^{+}$cells sense the pheromone they move almost three times quicker. In $S$. robusta natural pairing only occurs after 6 hrs (Chepurnov et al. 2008) but directed attraction was proven (Bondoc et al. 2016). A similar analysis of directed movement is crucial to determine whether chemotaxis is occurring in C. closterium as well.

Other than in S. robusta or P. trainorii the pheromone production in $C$. closterium is only dependent on cell size. As soon as $\mathrm{mt}^{-}$cells get sexualized they secrete the pheromone and unconditioned $\mathrm{mt}^{+}$cells are able to perceive the signal. In contrast, a reciprocal stimulation is known for $P$. trainorii where three different pheromones are involved in the sexual reproduction (Sato et al. 2011). The production of the attraction pheromone L-diproline in $S$. robusta is also induced by a sex inducing pheromone $\left(\mathrm{SIP}^{+}\right)$of $\mathrm{mt}^{+}$. Simultaneously, $\mathrm{mt}^{-}$produces $\mathrm{SIP}^{-}$that induces the development of a receptor in $\mathrm{mt}^{+}$(Moeys et al. 2016). 
Compared to $S$. robusta we confirm a rather short premating induction phase in $C$. closterium (Vanormelingen et al. 2013). We observed a cell cycle arrest in $\mathrm{mt}^{+}$cells induced by a cytostatic pheromone exuded by $\mathrm{mt}^{-}$similar to $S$. robusta. In $S$. robusta as well as $P$. multistriata both mating types are arrested in G1 of the cell cycle (Basu et al. 2017; Moeys et al. 2016). However, $\mathrm{mt}^{-}$cells in P. multistriata initiate the sexual process by undergoing meiosis earlier than $\mathrm{mt}^{+}$whose response is slightly out of phase. Difference in cell cycle progression of mating types is also known in $S$. robusta. G1 synchronized $\mathrm{mt}^{+}$cells progress in the cell cycle already three hours after light treatment whereas $\mathrm{mt}^{-}$only enter the G2/M phase after $9 \mathrm{~h}$ (Bilcke et al. 2020). The $\mathrm{mt}^{-}$cells in $C$. closterium further promote gametogenesis of $\mathrm{mt}^{+}$cells by producing another pheromone. Involvement of pheromones not only in the mate finding process but in the sexual reproduction itself is known for other pennate diatoms as well. In $P$. trainorii female cells secrete a pheromone responsible for the sexual stimulation of male cells (Sato et al. 2011) and in T. fasciculata gametogenesis is induced without cell contact (Davidovich et al. 2010).

Overall, the mating type behaviour and pheromone system of $C$. closterium has a unique complexity but includes aspects observed in other pennate diatoms like $S$. robusta and $P$. trainorii. Future experiments will focus on a metabolomics approach to chemically investigate the sexual phases of $C$. closterium in more detail and identify the attraction pheromone as well as the cytostatic pheromone (Fiorini et al. 2020; Gillard et al. 2013).

Supplementary Information The online version contains supplementary material available at https://doi.org/10.1007/s10886-021-01277-8.

\begin{abstract}
Acknowledgments The research leading to the results presented in this publication was partly carried out with infrastructure funded by EMBRC Belgium-FWO project GOH3817N and funding from the research council of Ghent University (BOF/GOA No. 01G01715). The authors are thankful for the provision of diatom strains by the BCCM/DCG culture collection. Further, the authors acknowledge the Cell Cycle Group at VIB-UGent Center for Plant Systems Biology for flow cytometer measurements. The authors are grateful to $M$. Vallet for her suggestions on the improvement of experimental set ups. R. X. Poulin's help with the design of the figures and his comments on an earlier version of the manuscript are highly appreciated.
\end{abstract}

Funding Open Access funding enabled and organized by Projekt DEAL.

Open Access This article is licensed under a Creative Commons Attribution 4.0 International License, which permits use, sharing, adaptation, distribution and reproduction in any medium or format, as long as you give appropriate credit to the original author(s) and the source, provide a link to the Creative Commons licence, and indicate if changes were made. The images or other third party material in this article are included in the article's Creative Commons licence, unless indicated otherwise in a credit line to the material. If material is not included in the article's Creative Commons licence and your intended use is not permitted by statutory regulation or exceeds the permitted use, you will need to obtain permission directly from the copyright holder. To view a copy of this licence, visit http://creativecommons.org/licenses/by/4.0/.

\section{References}

Abe T, Nakamura S, Kudo S (2017) Bioconvection induced by bacterial chemotaxis in a capillary assay. Biochem Biophys Res Commun 483:277-282. https://doi.org/10.1016/j.bbrc.2016.12.152

Amato A (2010) Diatom Reproductive Biology: Living in a Crystal Cage. J Plant Reprod Biol 2:1-10

Apoya-Horton MD, Yin L, Underwood GJC, Gretz MR (2006) Movement modalities and response to environmental changes of the mudflar diatom Cylindrotheca closterium (Bacillariophyceae). J Phycol 42:379-390. https://doi.org/10.1111/j.1529-8817.2006.00194.x

Armbrust EV (2009) The life of diatoms in the world's oceans. Nature 459:185. https://doi.org/10.1038/nature08057

Basu S et al (2017) Finding a partner in the ocean: molecular and evolutionary bases of the response to sexual cues in a planktonic diatom. New Phytol 215:140-156. https://doi.org/10.1111/nph.14557

Benoiston A-S, Ibarbalz FM, Bittner L, Guidi L, Jahn O, Dutkiewicz S, Bowler C (2017) The evolution of diatoms and their biogeochemical functions. Philos Trans R Soc Lond B Biol Sci 372:20160397. https://doi.org/10.1098/rstb.2016.0397

Bilcke $\mathrm{G}$ et al (2020) Mating type specific transcriptomic response to sex inducing pheromone in the pennate diatom Seminavis robusta. ISME J. https://doi.org/10.1101/2020.03.16.987719

Bondoc KGV, Lembke C, Lang SN, Germerodt S, Schuster S, Vyverman W, Pohnert G (2019) Decision-making of the benthic diatom Seminavis robusta searching for inorganic nutrients and pheromones. ISME J 13:537-546. https://doi.org/10.1038/s41396-018-0299-2

Bondoc KGV, Lembke C, Vyverman W, Pohnert G (2016) Searching for a Mate: Pheromone-Directed Movement of the Benthic Diatom Seminavis robusta. Microb Ecol 72:287-294. https://doi.org/10. 1007/s00248-016-0796-7

Bonneure E, De Baets A, De Decker S, Van den Berge K, Clement L, Vyverman W, Mangelinckx S (2021) Altering the Sex Pheromone Cyclo(L-Pro-L-Pro) of the Diatom Seminavis robusta towards a Chemical Probe. Int J Mol Sci 22:1037

Chepurnov V, Mann D, Sabbe K, Vyverman W (2004) Experimental Studies on Sexual Reproduction in Diatoms. Int Rev Cytol 237:91-154. https://doi.org/10.1016/S0074-7696(04)37003-8

Chepurnov VA et al (2005) Sexual reproduction, mating system, chloroplast dynamics and abrupt cell size reduction in Pseudonitzschia pungens from the North Sea (Bacillariophyta). Eur J Phycol 40:379-395. https://doi.org/10.1080/09670260500254735

Chepurnov VA et al (2008) search of new tractable diatoms for experimental biology. BioEssays 30:692-702. https://doi.org/10.1002/ bies. 20773

Chepurnov VA, Mann DG, Vyverman W, Sabbe K, Danielidis DB (2002) Sexual Reproduction, mating system, and protoplast dynamics of Seminavis (Bacillariophyceae). J Phycol 38:10041019. https://doi.org/10.1046/j.1529-8817.2002.t01-1-01233.x

D'Alelio D, Amato A, Luedeking A, Montresor M (2009) Sexual and vegetative phases in the planktonic diatom Pseudo-nitzschia multistriata. Harmful Algae 8. https://doi.org/10.1016/j.hal.2008.05.004

Davidovich AN (2001) Species specific sizes and size range of sexual reproduction in diatoms. Proc. 16th Int. Diatom Symp. (Athens and Aegean Islands, Aug. 25-Sept. 1, 2000), Athens: Univ. Athens

Davidovich AN, Kaczmarska I, Ehrman MJ (2010) Heterothallic and homothallic sexual reproduction in Tabularia fasciculata (Bacillariophyta). Fottea 10:251-266. https://doi.org/10.5507/fot.2010.016

Davidovich NA, Mouget J-L, Gaudin P (2009) Heterothallism in the pennate diatom Haslea ostrearia (Bacillariophyta). Eur J Phycol 44:251-261. https://doi.org/10.1080/09670260802710301 
Falkowski PG, Barber RT, Smetacek V (1998) Biogeochemical Controls and Feedbacks on Ocean Primary Production. Science 281:200. https://doi.org/10.1126/science.281.5374.200

Fiorini F, Borgonuovo C, Ferrante MI, Brönstrup M (2020) A Metabolomics Exploration of the Sexual Phase in the Marine Diatom Pseudo-nitzschia multistriata. Mar Drugs 18:313. https://doi.org/ 10.3390/md18060313

Frenkel J, Vyverman W, Pohnert G (2014) Pheromone signaling during sexual reproduction in algae. Plant J 79:632-644. https://doi.org/ 10.1111/tpj. 12496

Friedrich S, Konietschke F, Pauly M (2018) Analysis of Multivariate Data and Repeated Measures Designs with the R Package MANOVA.RM. New York

Gillard J et al (2013) Metabolomics Enables the Structure Elucidation of a Diatom Sex Pheromone. Angew Chem Int Ed 52:854-857. https://doi.org/10.1002/anie.201208175

Guillard RRL (1975) Culture of Phytoplankton for Feeding Marine Invertebrates. In: Smith WL, Chanley MH (eds) Culture of Marine Invertebrate Animals: Proceedings - 1st Conference on Culture of Marine Invertebrate Animals Greenport. Springer US, Boston, MA, pp 29-60. https://doi.org/10.1007/978-1-4615-8714-9_3

Lewis WM (1987) The cost of sex. In: Stearns S.C. (eds) The Evolution of Sex and its Consequences. Experienta Supplementum, vol 55. Birkhäuser, Basel

Malviya $S$ et al (2016) Insights into global diatom distribution and diversity in the world's ocean Proc Nat Acad Sci 113:E1516. https://doi.org/10.1073/pnas.1509523113

Moeys $\mathrm{S}$ et al (2016) A sex-inducing pheromone triggers cell cycle arrest and mate attraction in the diatom Seminavis robusta. Sci Rep 6:19252. https://doi.org/10.1038/srep19252

Najdek M, Blažina M, Djakovac T, Kraus R (2005) The role of the diatom Cylindrotheca closterium in a mucilage event in the northern Adriatic Sea: coupling with high salinity water intrusions. J Plankton Res 27:851-862. https://doi.org/10.1093/plankt/fbi057

Nakov T, Beaulieu JM, Alverson AJ (2018) Accelerated diversification is related to life history and locomotion in a hyperdiverse lineage of microbial eukaryotes (Diatoms, Bacillariophyta). New Phytol 219:462-473. https://doi.org/10.1111/nph.15137

Osuna-Cruz CM et al (2020) The Seminavis robusta genome provides insights into the evolutionary adaptations of benthic diatoms. Nat Commun 11:3320. https://doi.org/10.1038/s41467-020-17191-8

Poulíčková A, Mann DG (2019) Diatom Sexual Reproduction and Life Cycles. In: Diatoms: Fundamentals and Applications. pp 245-272. https://doi.org/10.1002/9781119370741.ch11
Russo MT et al (2018) MRP3 is a sex determining gene in the diatom Pseudo-nitzschia multistriata. Nat Commun 9:5050-5050. https:// doi.org/10.1038/s41467-018-07496-0

Sato S, Beakes G, Idei M, Nagumo T, Mann DG (2011) Novel Sex Cells and Evidence for Sex Pheromones in Diatoms. PLoS ONE 6:e26923. https://doi.org/10.1371/journal.pone.0026923

Scalco E, Amato A, Ferrante MI, Montresor M (2016) The sexual phase of the diatom Pseudo-nitzschia multistriata: cytological and time-lapse cinematography characterization. Protoplasma 253:1421-1431. https://doi.org/10.1007/s00709-015-0891-5

Scalco E, Stec K, Iudicone D, Ferrante MI, Montresor M (2014) The dynamics of sexual phase in the marine diatom Pseudo-nitzschia multistriata (Bacillariophyceae). J Phycol 50:817-828. https://doi. org/10.1111/jpy. 12225

Smetacek V (1998) Diatoms and the silicate factor. Nature 391:224 225. https://doi.org/10.1038/34528

Stal LJ, Bolhuis H, Cretoiu MS (2019) Phototrophic marine benthic microbiomes: the ecophysiology of these biological entities. Environ Microbiol 21:1529-1551. https://doi.org/10.1111/1462-2920. 14494

Stock W, Vanelslander B, Rüdiger F, Sabbe K, Vyverman W, Karsten U (2019) Thermal Niche Differentiation in the Benthic Diatom Cylindrotheca closterium (Bacillariophyceae) Complex Front Microbiol 10. https://doi.org/10.3389/fmicb.2019.01395

Team RC (2016) R: A Language and Environment for Statistical Computing. vol 1. Vienna, Austria. https://doi.org/10.1890/00129658(2002)083[3097:CFHIWS]2.0.CO;2

Vanormelingen P, Vanelslander B, Sato S, Gillard J, Trobajo R, Sabbe K, Vyverman W (2013) Heterothallic sexual reproduction in the model diatom Cylindrotheca. Eur J Phycol 48:93-105. https://doi. org/10.1080/09670262.2013.772242

Vanstechelman I, Sabbe K, Vyverman W, Vanormelingen P, Vuylsteke M (2013) Linkage Mapping Identifies the Sex Determining Region as a Single Locus in the Pennate Diatom Seminavis robusta. PLoS ONE 8:e60132. https://doi.org/10.1371/journal.pone.0060132

von Quillfeldt CH, Ambrose WG, Clough LM (2003) High number of diatom species in first-year ice from the Chukchi Sea. Polar Biol 26:806-818. https://doi.org/10.1007/s00300-003-0549-1

Yallop ML, de Winder B, Paterson DM, Stal LJ (1994) Comparative structure, primary production and biogenic stabilization of cohesive and non-cohesive marine sediments inhabited by microphytobenthos. Estuar Coast Shelf Sci 39:565-582. https://doi.org/10. 1016/S0272-7714(06)80010-7 